\title{
AMENDMENTS
}

\section{Publisher Correction: Determination of isoform-specific RNA structure with nanopore long reads}

Jong Ghut Ashley Aw (D), Shaun W. Lim, Jia Xu Wang (D), Finnlay R. P. Lambert, Wen Ting Tan, Yang Shen, Yu Zhang (iD, Pornchai Kaewsapsak, Chenhao LiD, Sarah B. Ng, Leah A. Vardy D, Meng How Tan, Niranjan Nagarajan (D) and Yue Wan

Correction to: Nature Biotechnology https://doi.org/10.1038/s41587-020-0712-z, published online 26 October 2020.

In the version of this article initially published online, the accompanying Nature Research Reporting Summary was for a different paper. The error has been corrected in the PDF and HTML versions of the article.

Published online: 23 March 2021

https://doi.org/10.1038/s41587-021-00889-5

๑) The Author(s), under exclusive licence to Springer Nature America, Inc. 2021

\section{Publisher Correction: A genomic catalog of Earth's microbiomes}

Stephen Nayfach, Simon Roux, Rekha Seshadri, Daniel Udwary (D), Neha Varghese, Frederik Schulz (D), Dongying Wu, David Paez-Espino (iD, I-Min Chen (D), Marcel Huntemann (D), Krishna Palaniappan, Joshua Ladau, Supratim Mukherjee (D), T. B. K. Reddy (D), Torben Nielsen, Edward Kirton, José P. Faria, Janaka N. Edirisinghe, Christopher S. Henry, Sean P. Jungbluth, Dylan Chivian (D, Paramvir Dehal, Elisha M. Wood-Charlson (D), Adam P. Arkin, Susannah G. Tringe (D), Axel Visel (D), IMG/M Data Consortium*, Tanja Woyke (D), Nigel J. Mouncey (D), Natalia N. Ivanova (D), Nikos C. Kyrpides (iD) and Emiley A. Eloe-Fadrosh (D)

Correction to: Nature Biotechnology https://doi.org/10.1038/s41587-020-0718-6, published online 9 November 2020.

This paper was originally published under standard Springer Nature copyright (@ The Author(s), under exclusive licence to Springer Nature America, Inc.). It is now available as an open-access paper under a Creative Commons Attribution 4.0 International license. The error has been corrected in the print, HTML and PDF versions of the article.

${ }^{\star}$ A list of authors and their affiliations appears online.

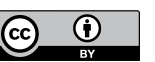

Open Access This article is licensed under a Creative Commons Attribution 4.0 International License, which permits use, sharing, adaptation, distribution and reproduction in any medium or format, as long as you give appropriate credit to the original author(s) and the source, provide a link to the Creative Commons license, and indicate if changes were made. The images or other third party material in this article are included in the article's Creative Commons license, unless indicated otherwise in a credit line to the material. If material is not included in the article's Creative Commons license and your intended use is not permitted by statutory regulation or exceeds the permitted use, you will need to obtain permission directly from the copyright holder. To view a copy of this license, visit http://creativecommons.org/ licenses/by/4.0/.

Published online: 18 November 2020

https://doi.org/10.1038/s41587-020-00769-4

() The Author(s) 2020 